\title{
THE ROLE OF POLITICS IN FINANCIAL CRISES IN EMERGING
}

\section{Paola L. Montero Ledezma}

\begin{abstract}
In this paper, we embed the key political mechanis ms, specific to developing countries, into a political-economic model of financial crises. In this setup, financial market failures allow opportune government intervention to restore optimal allocation of resources. However, bad public policies could provoke financial crises. We find that the political interests and individuals' 1-dimensional heterogeneity, in terms of productivity, lead to different preferred policies between the median-productive and mean-productive economic agents, which might in turn induce to bad public intervention. Therefore, the larger the difference between these two reference individuals, the higher the probability of financial crises. We also discuss some features of the financial crises in Argentina (2001-2002) and its similarities with our model.
\end{abstract}

Keywords: Financial Crises, Political Economy, Emerging Markets, Government Intervention.

DOI: $10.23881 /$ idupbo.018.2-1e 